\title{
MATRIX OF FUNCTION AND FUNCTIONALITY AS A TOOL IN PRODUCT DEVELOPMENT PROCESS
}

\author{
Mirko Karakašić, Žiga Zadnik, Milan Kljajin, Jože Duhovnik
}

Original scientific paper

The paper describes the use of MFF (Matrix of function and functionality) as a tool in product development process. After years of analysis of matrix methods, functions and functionalities of the products, we have developed a matrix tool that is designed for a wide range of engineers to help developing of new products or their parts. The paper presents the core of the MFF, that is the mathematical model and the computer application. Basic idea was to create an innovative knowledge base in a specific area that contains at one place the knowledge of engineers acquired during their working life, or during product development. With MFF it is possible to generate completely new products with new functional structures where functions are unambiguously described by physical sizes - influencing the functions.

Keywords: design process; function; functionality; MFF; product development

Matrica funkcije i funkcionalnost kao alat u procesu razvoja proizvoda

Izvorni znanstveni članak

U radu je opisana MFF (matrica funkcije i funkcionalnosti) kao alat koji se koristi u procesu razvoja proizvoda. Nakon nekoliko godina istraživanja matričnih metoda, funkcija i funkcionalnosti proizvoda, razvili smo matrični alat kao pomoć inženjerima u razvoju novih proizvoda i njihovih komponenti. U radu je prikazana jezgra MFF, a to su matematički model i računalna aplikacija. Osnovna ideja bila je napraviti bazu podataka u određenom području koja na jednom mjestu sadrži stečeno cjeloživotno inženjersko znanje, ili znanje nastalo za vrijeme procesa razvoja proizvoda. Pomoću MFF moguće je generirati potpuno nove proizvode i njihove funkcijske strukture, gdje su funkcije jednoznačno opisane pomoću fizikalnih veličina-koje utječu na funkcije.

Ključne riječi: funkcija; funkcionalnost; konstrukcijski proces; MFF; razvoj proizvoda

\section{Introduction}

The conceptual design stage is one of the first stages in the product development process. This stage is crucial since it is most influential in the success or failure of a product to achieve its target goals. However, information used in this stage is quite uncertain and the space of possibilities is large and could be expanded further. Therefore, it is difficult to develop a systematic approach to generate good design concepts. The classic method of morphological chart [1] for recording the options and heuristically coming up with solutions is very limited [2]. In the design process Suh made some research and he found a connection between the function, design and manufacturing matrix [3]. He tried the winning parameters and decided that just one parameter was important; all the others depended on it. The process defined in that way is very common for simplifying the problem, but for searching a way for the sophisticated product we lose the creative way of the design.

Among the most important facts in the conceptual stage are market requirements which are defined by customer and/or users expectation. They represent the basis for defining the basic functional requirements, which in turn represent the initial information about a new, potential product [4]. Requirements are unarranged, incomplete, which makes it necessary for them to be arranged, completed and expanded. Nowadays, new methods such as the FFF [5] and eFFF [6] are developed. The eFFF method defines the universally necessary requirements, product-specific necessary requirements and optional requirements.

When the goal is to create design solutions that have not previously existed, the functional requirements must be defined in a solution neutral environment (functional space) [7]. The functional requirements and solutions are always visible in the form of technical functions and technical systems, where according to Hubka and Eder [8], a technical system is defined as an artefact. A technical system is also a functional and a material system, which by fulfilling functions satisfies the needs, and this gives people the possibility to realize one or more values [9].

There are many different definitions and descriptions of functions. According to Hubka and Eder a function is a property of the technical system and describes its ability to fulfil a purpose, namely, to convert an input measure into the required output measure under precisely defined conditions. Suh understands function as the desired output, while with the word physical we include all those things that generate the desired output [7].

To better understand the complexities of functions and other entities, special rules were created [10]. These rules were defined [8] in such a way that functions, functionalities, and products are described. The base point was the study by Duhovnik and Tavčar [11]. The functions are described by parameters which are based on physical laws.

In the studies by $[11,12]$, matrix models were initially developed and presented. Using these models it is possible to generate a functional structure of the product. The structure is described by matrix form and makes foundation for physical (shape) structure of a product.

Research and development activities within the product development process have their own characteristic and distinctive features, dominated by unpredictability, creativity, mentality and abstraction. Due to these features it is difficult to thoroughly describe, develop and implement the design process in the initial phases of computer-tools development $[13,14]$. But in the 
environment of concurent engineering product development process, it is important to increase productivity, product quality and reduce product development time [4]. Product development time depends on the product development stages and the multiple information transfer of partially or fully built information. This is possible when the functional requirements are properly recognized, developed and evaluated. When the pieces of information are built concurrently, they can be transferred between stages, which in the end can be viewed as a shortened production process.

In order to reduce the time and costs involved in solving and improving the functional requirements, there is an increasing demand for new methods that would enable the concurrent and parallel solving of objectives [15]. Hence it is crucial that the new methods are implemented in computer applications decreasing costs and product development time.

\section{The MFF model}

The matrix of function and functionality - MFF - is a methodology that can serve an individual, i.e. a designer, to find and analyse various solutions of functional requirements in a repeatable way. In the later stages of design process, it allows easier generation of product's new and variant functional and physical structures. The MFF represents a tabular representation of bindings between function requests and functionalities. It is possible to say that MFF is a connection among functional domain and design elements domain (Fig. 1). It is built and defined on the basis of a mathematical model [16] and pre-set rules, not just on the basis of design intuition. In the functionality domain we represent all details form, which are directly dependent on the manufacturing technology. Additionally we can also represent the form of the physical structure of the products which makes direct relation with the mechanic, electrical, optics and nuclear laws and relation.

The MFF is used when we want to improve the initial engineering process (conceptual phase), where only the basic information is available. MFF represents a tool with which it is possible in the preliminary phase to concurrently solve several functional requirements and generate new functional and design structures of a product. Functional requests are derived from market requirements and they represent the most important attributes of the requested system - functions while functionalities are represented by technical systems or shape models that partially or fuly fulfill the required functions.

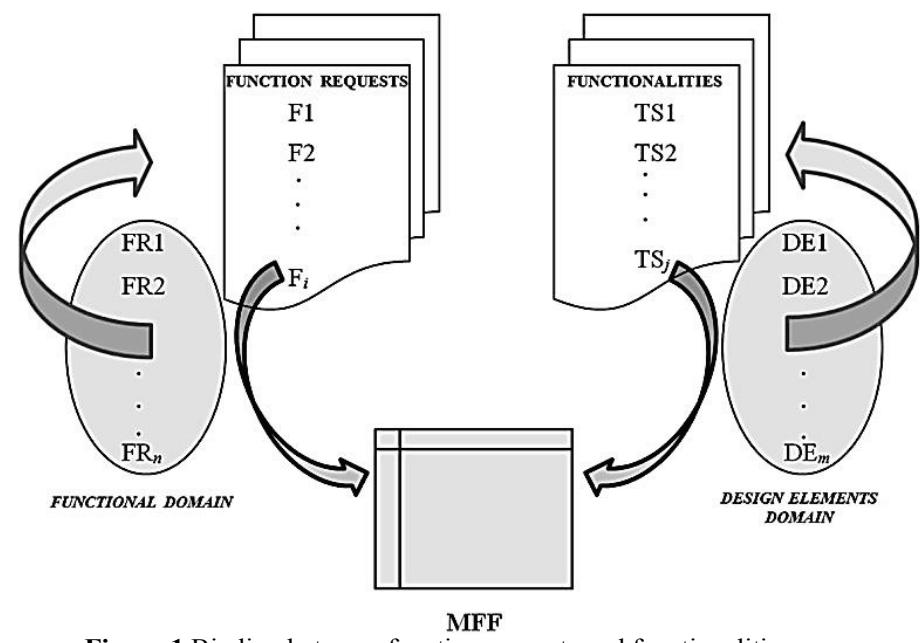

Figure 1 Binding between function requests and functionalities

A general model of MFF is presented in Fig. 2. Relations between functions and functionalities are represented by sub-matrices. Sub-matrices present possible solutions of functions. Functional requirements in MFF model are marked with Fi and are placed in the (functionalities) are marked with $\mathrm{TS} j$ and can be found in subsequent columns. first column, while individual technical systems

\begin{tabular}{|c|c|c|c|c|}
\hline \multirow{2}{*}{ FUNCTION } & \multicolumn{4}{|c|}{ FUNCTIONALITY / SOLUTION } \\
\hline & TS1 $\rightarrow$ & $\leftarrow \mathrm{TS} 2 \rightarrow$ & $\leftarrow$ TS3 $\rightarrow$ & $\leftarrow \mathrm{TS} j$ \\
\hline \multirow{2}{*}{$\begin{array}{c}\text { Functional requirement } \\
-\mathrm{F} 1 \\
\text { [Suggested solution] }\end{array}$} & M $88 \downarrow$ & & M 30 † & \\
\hline & $\uparrow 549$ & & $\uparrow \mathrm{A} 40$ & \\
\hline \multirow{4}{*}{$\begin{array}{c}\text { Functional requirement } \\
-\mathbf{F 2} \\
\text { [Suggested solution] }\end{array}$} & & $585 \downarrow$ & & M $100 \downarrow$ \\
\hline & & $\uparrow S 45 \downarrow$ & & $\uparrow \mathrm{A} 100 \downarrow$ \\
\hline & & $\uparrow \mathrm{B} 23 \downarrow$ & & ^ B $56 \downarrow$ \\
\hline & & † B 15 & & † B 33 \\
\hline \multicolumn{5}{|l|}{ 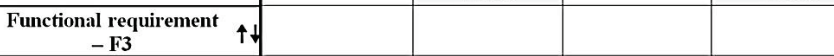 } \\
\hline \multirow{2}{*}{$\begin{array}{c}\text { Functional requirement } \\
-\mathbf{F} 4 \\
\text { [Suggested solution] }\end{array}$} & \multirow{2}{*}{ M 100} & M $88 \downarrow$ & & M $88 \downarrow$ \\
\hline & & $\uparrow \mathrm{S} 49$ & & $\uparrow \mathrm{s} 49$ \\
\hline $\begin{array}{c}\text { Functional requirement } \\
-\mathbf{F} i \\
\text { [Suggested solution] }\end{array}$ & M 80 & & & \\
\hline
\end{tabular}


MFF tends to find new design solutions for specified functional requirements, where an individual's intuition and experiences are not required. Even non-experienced engineer can generate and evaluate solutions (products). MFF uses the basics of technical functions [17], rules for describing and arranging functions into main, supplementary, auxiliary and binding functions [10] and characteristics of describing them with parameters and winning parameters.

Before MFF, the matrix of product function and its requirements was developed as a prototype to the MFF. The basic idea for making application was to create a knowledge base in a specific area that contained at one place the knowledge of engineers acquired during their working life, or during product development. The knowledge base is designed as an extensible base which would be expanding by every new designed product and in that way become better and more useful.

The knowledge base is formed automatically by inputting the individual characteristics of the product, determined by the main, supplementary, auxiliary and binding functions [10] (Fig. 3). Each product comprises records of at least one main, one or more auxiliary and supplementary functions, and at least two or more binding ones. Functions have also been described with the physical values of parameters [16].

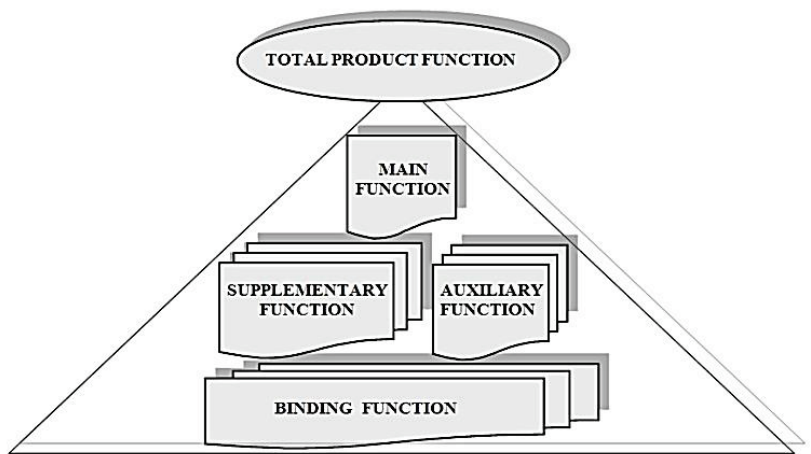

Figure 3 Overall function of a technical system

\section{Mathematical model of MFF}

Mathematical form of MFF (Fig. 4) is based on a matrix expression and direct connection between functional requirements $F_{i} ; i=1, \ldots, n$ and functionalities $T S_{j} ; j=1, \ldots, m$ where the following applies:

Functional requirements $F_{i}$ are marked with corresponding marks and the following applies:

$$
F_{1}, F_{2}, F_{3}, \ldots, F_{n} ; \forall n \in \mathrm{N}
$$

Functionalities $T S_{j}$ are marked with corresponding marks and the following applies:

$$
T S_{1}, T S_{2}, T S_{3}, \ldots, T S_{m} ; \forall m \in \mathrm{N}
$$

Individual cross-sections $F_{i} \cap T S_{j}$ or $T S_{j} \cap F_{i}$ (solutions, i.e. sub-matrices) are defined as (Fig. 5) and the following applies:

$$
\begin{aligned}
& F_{i} \cap T S_{j}=T S_{j} \cap F_{i}, \\
& F_{i} \cap T S_{j}=\left\{X_{F_{i}, T S_{j}} \mid X_{F_{i}, T S_{j}} \in F_{i} \wedge X_{F_{i}, T S_{j}} \in T S_{j}\right\} \\
& i=1, \ldots, n ; j=1, \ldots, m .
\end{aligned}
$$

\begin{tabular}{|c|c|c|c|c|}
\hline \multirow{2}{*}{$\mathbf{F}$} & \multicolumn{4}{|c|}{ TS } \\
\hline & $\mathrm{TS}_{1}$ & $\mathbf{T S}_{2}$ & $\ldots$ & $\mathbf{T S}_{m}$ \\
\hline $\begin{array}{c}F_{1} \\
{\left[R_{F_{1}}\right]}\end{array}$ & $\mathrm{X}_{\mathrm{F} 1, \mathrm{TS} 1}$ & $\mathrm{X}_{\mathrm{F} 1, \mathrm{TS} 2}$ & $\cdots$ & $\mathrm{X}_{\mathrm{F} 1, \mathrm{TS}}$ \\
\hline $\begin{array}{c}F_{2} \\
{\left[R_{F_{2}}\right]}\end{array}$ & $\mathrm{X}_{\mathrm{F} 2, \mathrm{TS} 1}$ & $\mathrm{X}_{\mathrm{F} 2, \mathrm{TS} 2}$ & $\ldots$ & $\mathrm{X}_{\mathrm{F} 2, \mathrm{TS} \mathrm{m}}$ \\
\hline $\begin{array}{c}F_{3} \\
{\left[R_{F_{3}}\right]}\end{array}$ & $\mathrm{X}_{\mathrm{F} 3, \mathrm{TS} 1}$ & $\ldots$ & $\cdots$ & $\mathrm{X}_{\mathrm{F} 3, \mathrm{TSm}}$ \\
\hline$\vdots$ & $\vdots$ & $\ldots$ & $\because$ & $\vdots$ \\
\hline $\begin{array}{c}F_{n} \\
{\left[R_{F_{n}}\right]}\end{array}$ & $\mathrm{X}_{\mathrm{F}, \mathrm{TS} 1}$ & $\mathrm{X}_{\mathrm{Fn}, \mathrm{TS} 2}$ & $\cdots$ & $\mathrm{X}_{\mathrm{F}_{\mathrm{n}}, \mathrm{TS} \mathrm{m}}$ \\
\hline
\end{tabular}

Figure 4 Mathematical form of MFF

All cross-sections (solutions, sub-matrices), belonging to the one functional requirement, are written as:

$R_{F_{i}}=\left\{X_{F_{i}, T S_{1}}, X_{F_{i}, T S_{2}}, X_{F_{i}, T S_{3}}, \ldots, X_{F_{i}, T S_{m}}\right\}$

where $i=1, \ldots, n$.

All cross-sections (solutions, sub-matrices), belonging to one functionality, are written as:

$R_{T S_{j}}=\left\{X_{F_{1}, T S_{j}}, X_{F_{2}, T S_{j}}, X_{F_{3}, T S_{j}}, \ldots, X_{F_{n}, T S_{j}}\right\}$,

where $j=1, \ldots, m$.

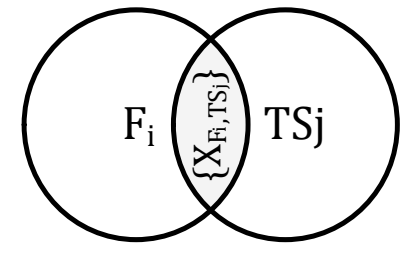

Figure 5 Cross-section (solution, sub-matrix) $F_{i} \cap T S_{j}=X_{F_{i}, T S}$

\section{Computer application of MFF}

The MFF application is designed, as a computer tool, for a wide range of engineers to help development of new products or their parts. The matrix of product function and its requirements was developed as a prototype to the MFF. The basic idea for making application was to create a knowledge base in a specific area. The knowledge base is designed as an extensible base which would be expanding by every new designed product and in that way become better and more useful. In addition to engineers beginners, this knowledge base is also very useful for experienced engineers, because it allows them to have available at one place their previous products solutions, but also the products solutions of other experienced engineers. In this way an engineer can quickly resolve 
problems encountered during the new product development and its design.

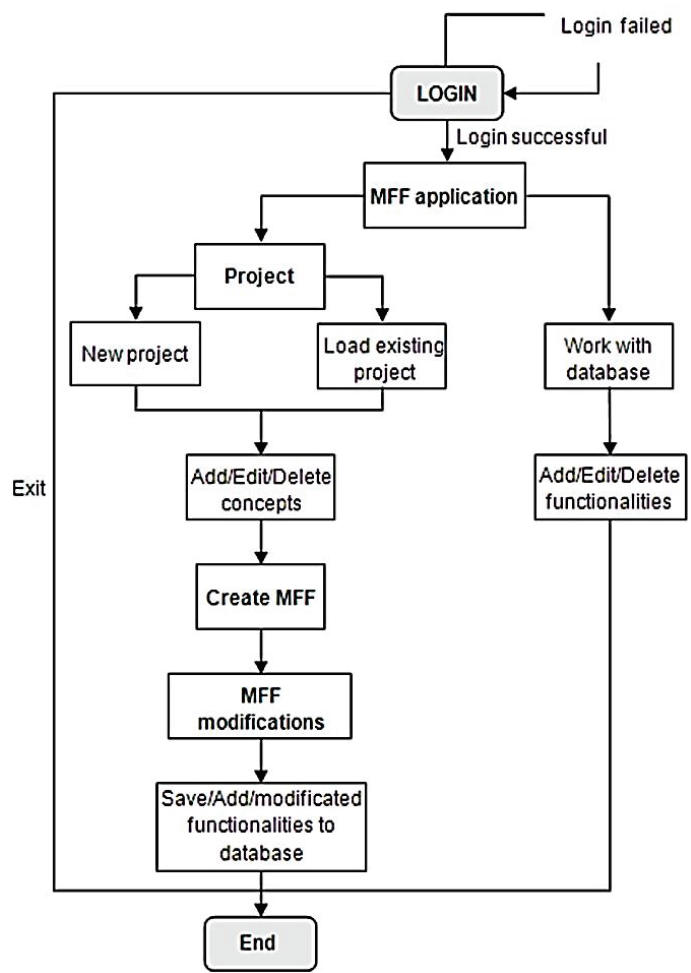

Figure6 MFF application flow chart

Fig. 6 presents a flow diagram of the MFF application. There are two ways to work with the application. First way is filling the knowledge base, second is to use the knowledge base to create new products. Using the application it is possible to simultaneously use both modes so it is possible to add new functionality during the development of new products.

The knowledge base is fulfilled by inputting the individual characteristics of products. These characteristics are determined by the main, supplementary, auxiliary and binding functions [10]. Functions are described with the values of the physical parameters [16].The rules for entry into the knowledge base functions are determined and are built into the system.

The system has a built-in decision tree and recognition of each function so that the percentages to calculate the satisfaction of each function are calculated. After the calculation of the matrix, the user can make modifications so as to reach the final solution to the concrete problem.

\section{Implementation}

The gap between theory and practice is of concern today. Effective methods need to be developed for transferring research results to industry, therefore MFF model was developed and verified with several products. The MFF model is currently presented and implemented on more than twenty completely different, solved and described products from diverse design areas. Some of them are presented in Fig. 7. An example of one of such products-suction unit/car vacuum cleaner is presented in Fig. 8.

Magnitude of MFF depends on the number of rows and columns. These numbers are in correlation with the number of functional requirements and number of functionalities. If the product is very complex, the number of functional requirements (rows) is very heavy. In that case the number of functionalities (columns) is large.

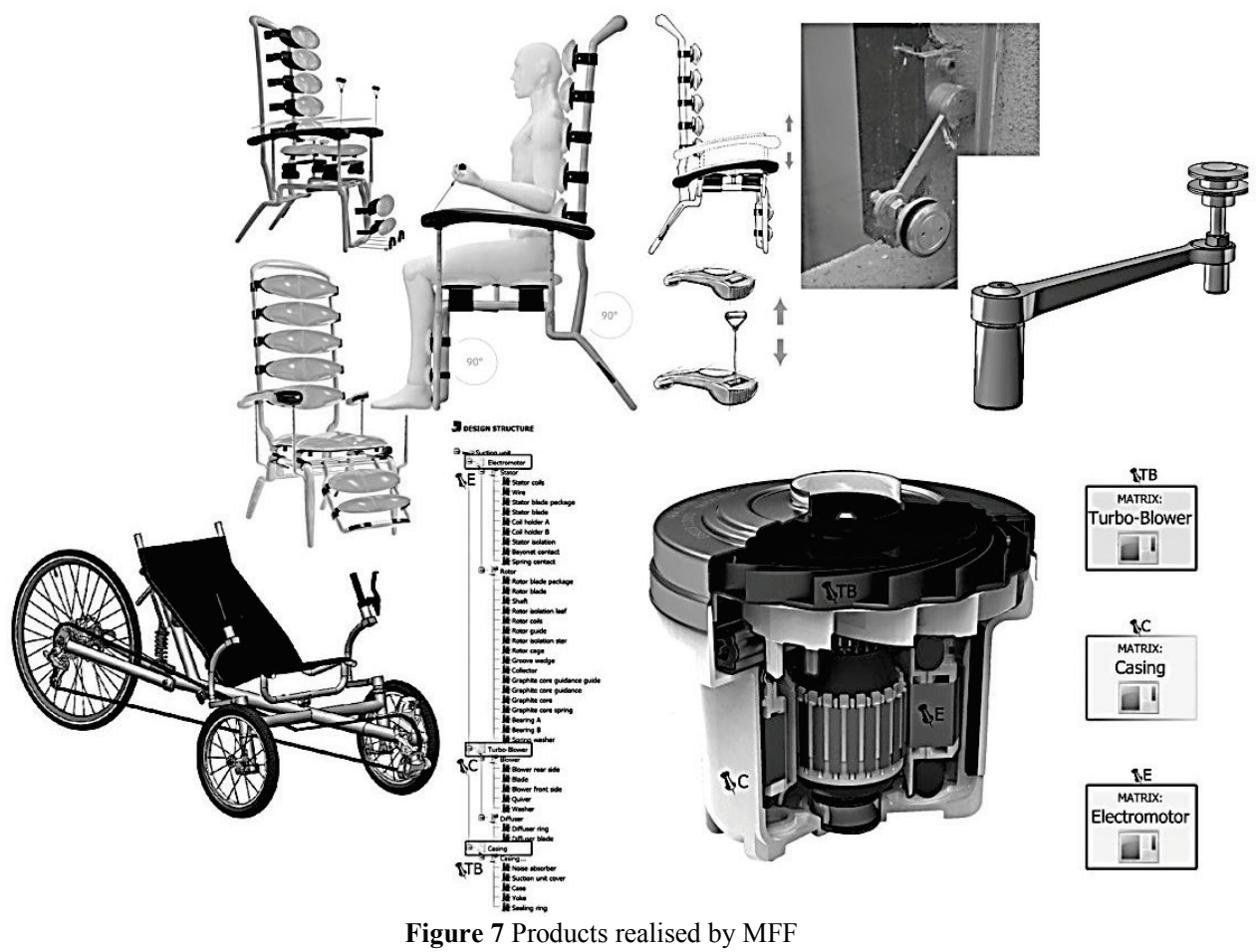

MFF can be used as a multidimensional matrix. Dimensions perform layers and layers perform a product structure, called a matrix structure [12]. This way a complete product structure is stored inside the MFF 
structure. Detailed functional structure is also created in MFF structure (Fig. 9). This relation is represented in submatrices inside MFF (Fig. 8).

Solutions are presented as perceptual values, where, by logic, a higher value represents a more appropriate solution. Because each solution arises from the corresponding function on a defined functionality, as a consequence, it also contains additional data derived from this functionality (Fig. 8). Those additional data (parameters, intervals, descriptions, etc.) can also be taken into account when deciding on a final solution. This means that another solution, despite a lower level of the cross-section value, may be better than the highly rated solution.

Detail descriptions of MFF implementation are presented in $[12,16]$.

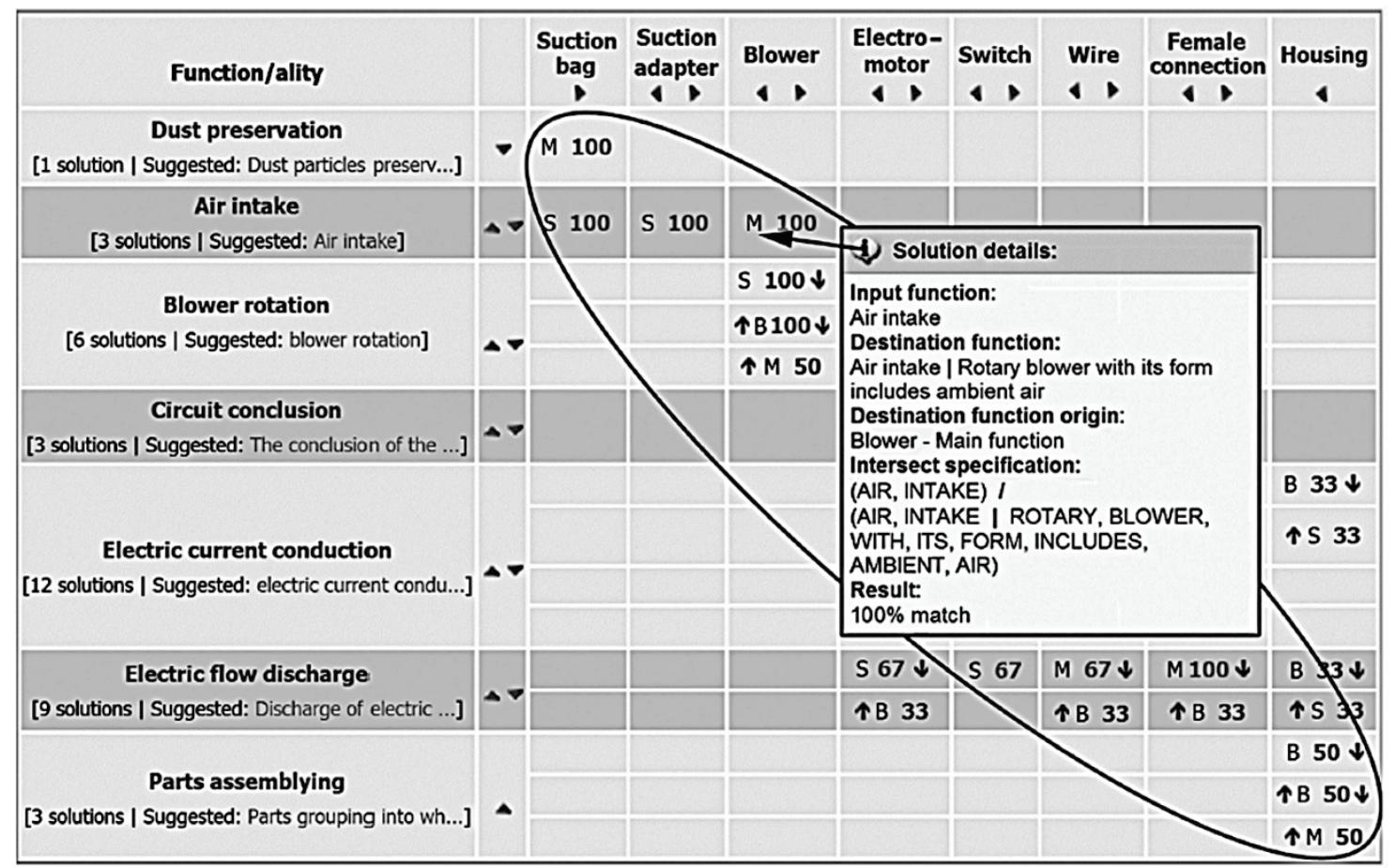

Figure 8 MFF with relations between functional requirements and functionalities

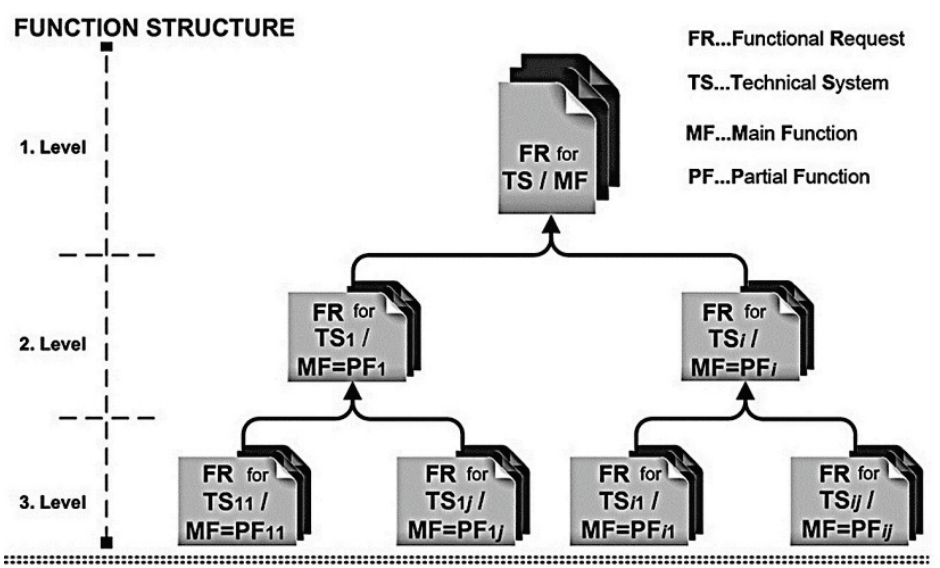

MATRIX STRUCTURE

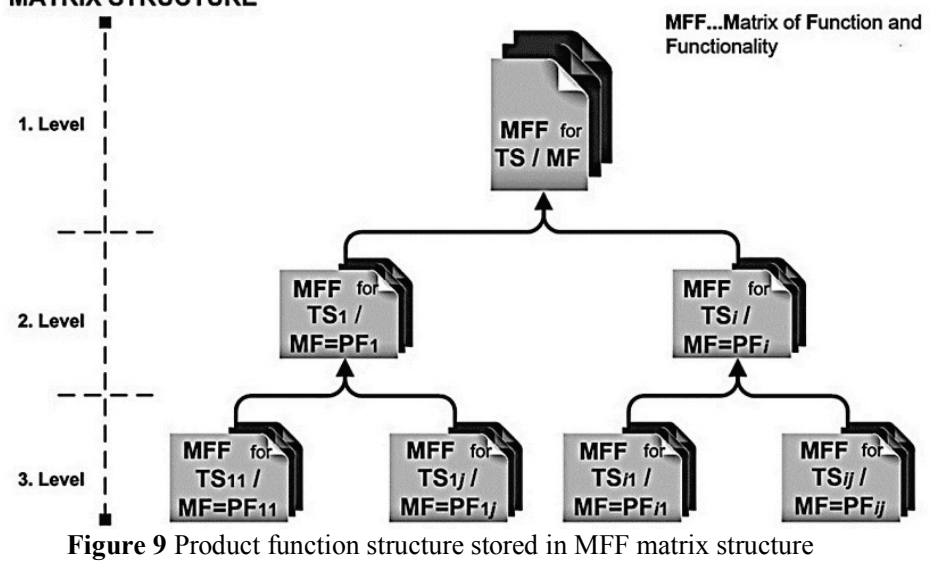




\section{Conclusion}

A short review of the current implementation of developed MFF model on specific products is presented. The main contribution of the MFF method is the possibility of concurrent development for activities in all phases of the preliminary design and development process. The MFF method allows solving of several open functional requirements, which recognizes the requirements for productivity, the clear recognition of generators, binders and information users, significantly increasing the product quality and the reduction of design and product-development times.

Compared to other methods, as the morphological matrix, the MFF method is designed mathematically and unintuitively, taking account of abstract and semantic guidelines, it uses function descriptions, it allows prompt control and the repeatability of solving, independent of the designer.

The MFF method is implemented in Web application, i.e. a software programme has been developed. On the basis of the MFF method is enabled advanced solving, collecting and processing of data on a future product.

In the paper mutual effects between the function and functionality in theoretical and practical field are established and described.

Possibility of generating functional structure, stored in matrix structure, enables a full review of data to designer. These data describe product and present design knowledge stored in MFF. By using MFF it is possible to use these data for new product design.

Future work would include development of a knowledge base in a specific area that contains at one place the knowledge of engineers acquired during their working life, or during product development.

MFF system can be used also for system analysis or prediction of a new family of products. This presents the idea that with MFF we can also include the products from the market which are already presented and have the standard quality for some function. Thus each user can build his or her base of standard semi-finished products, which is an essential advantage of our affordable system analysis.

\section{References}

[1] Zwicky, F. The morphological method of analysis and construction. Courant, New York: Intersciences, 1948

[2] Rosenstein, D.; Yoram, R. Hierarchical system concept generation. // Proceedings of the $18^{\text {th }}$ International Conference on Engineering Design (ICED11). / Kobenhavn, 2011, pp. 24-34.

[3] Suh, N. Axiomatic design-advances and applications. Oxford: Oxford University Press, 2001.

[4] Duhovnik, J.; Kušar, J.; Tomaževič, R. et al. Development process with regard to customer requirements. // Concurent Engineering: Research and Applications. 14, 1(2006), pp. 67-82.

[5] Criscimagna, N. H. Form, fit, function and interface - an element of an open system strategy. // The Journal of the Reliability Analysis Center. First quarter (2005), pp. 7-14

[6] Brglez, Š.; Dolšak, B. A discussion on new necessity based method for requirements list elicitaion and requirements classification. // Tehnicki vjesnik-Technical Gazette. 23, 4(2016), pp. 1095-1102. DOI: 10.17559/TV. 20150827152610

[7] Nam, P. and Suh, N. The principles of design. New York: Oxford University Press Inc., 1990.

[8] Hubka, V.; Eder, W. E. Theory of technical systems. Berlin; Heidelberg: Springer-Verlag, 1988. DOI: 10.1007/978-3-642-52121-8

[9] Roozenburg, N. F. M.; Eekels, J. Product design: fundamentals and methods. New York: John Wiley \& Sons Ltd., 1995.

[10] Zadnik, Ž.; Karakašić, M.; Kljajin, M.; Duhovnik, J. Functional and functionality in the conceptual design process. // Journal of Mechanical Engineering. 55, 7 8(2009), pp. 455-471.

[11] Duhovnik, J. and Tavčar, J. Product design test using the matrix of functions and functionality. // Proceedings of AEDS 2005 workshop. / Pilsen, 2005.

[12] Karakašić, M.; Zadnik, Ž.; Kljajin, M.; Duhovnik, J. Functional structure generation within multi-structured matrix forms. // Tehnicki vjesnik-Technical Gazette. 17, 4(2010), pp. 465-473.

[13] Ball, L. Design requirements, epimistic uncertainty and solution development strategies in software design. // Design Studies, 31, 6(2010). DOI: 10.1016/j.destud.2010.09.003

[14] Kurtoglu, T. A Computational Approach to Innovative Conceptual Design. PhD Thesis, The University of Texas at Austin, 2007.

[15] Hales, C.; Wallace, K. Design research reflections-30 years on. // Proceedings of the $18^{\text {th }}$ International Conference on Engineering Design (ICED11). / Kobenhavn, 2011, pp. 163-173.

[16] Zadnik, Ž. Matrika funkcij in funkcionalnosti izdelka v razvojno konstrukcijskem procesu. Doktorsko delo, Univeza v Ljubljani, Fakulteta za strojništvo, Ljubljana, 2012

[17] Houkes, W.; Vermaas, P. E. Technical Functions - On the Use and Design of Artefacts. New York: Springer Science+Business Media B.V., 2010.

\section{Authors' addresses}

Mirko Karakašić, assistant professor

Mechanical Engineering Faculty in Slavonski Brod,

J. J. Strossmayer University of Osijek,

Trg Ivane Brlić-Mažuranić 2

35000 Slavonski Brod, Croatia (EU)

E-mail: mirko.karakasic@sfsb.hr

Žiga Zadnik, dr. sc.

Akrapovič d.d.

Malo Hudo 8a,

1295 Ivančna Gorica, Slovenia (EU)

E-mail: ziga.zadnik@akrapovic.com

Milan Kljajin, full time professor

Mechanical Engineering Faculty in Slavonski Brod,

J. J. Strossmayer University of Osijek,

Trg Ivane Brlić-Mažuranić 2,

35000 Slavonski Brod, Croatia (EU)

E-mail:mkljajin@sfsb.hr

Jože Duhovnik, full time professor

Faculty of Mechanical Engineering,

University of Ljubljana,

Aškerčeva 6, 1000 Ljubljana, Slovenia (EU)

E-mail: joze.duhovnim@fs.uni-lj.si 